\title{
THE UNITED STATES AND THE WORLD NEED AN INTERNATIONAL CRIMINAL COURT AS AN ALLY IN THE WAR AGAINST TERRORISM
}

There is nothing more difficult to carry out, nor more doubtful of success, nor more dangerous to handle than to initiate a new order of things. For the reformer has enemies in all those that profit by the old order, and only lukewarm defenders in all those who would profit by the new order ....

Niccolo Machiavelli

The Prince

\section{INTRODUCTION}

The world continues to be plagued by international terrorism. ${ }^{2}$ The epidemic is exacerbated by the ability of terrorists to avoid prosecution by seeking refuge in nations that distrust the judicial system of the victimized state. ${ }^{3}$ Meanwhile, the world stands on the verge of creating a permanent international criminal court. ${ }^{4}$ Though it began as an amorphous concept, the quest to establish a permanent international criminal court has recently evolved into a well-developed framework. In fact, the world is likely to see the establishment of the first international criminal court to prosecute the perpetrators of global offenses in 1997 or $1998 .^{5}$

A major issue yet to be resolved surrounding the creation of the court is over which offenses the proposed tribunal should be given jurisdiction. ${ }^{6}$ The United States has urged that the jurisdiction of the tribunal be drawn narrowly to encompass only three crimes: (1) genocide, (2) crimes against humanity, and (3) serious violations of the laws applicable in an armed conflict or war crimes. ${ }^{7}$ However, other nations have argued that the

1. 1994 ILC Draft Statute for an International Criminal Court, U.N. GAOR, 50th Sess., at iii, U.N. Doc. A/Res 50/46 (1995) (quoting Niccolo MaChIAvelli, The PRINCE 15 (1513)).

2. See generally U.S. DePARTMENT OF STATE, 1996 APRIL: PATTERnS OF Global TERRORISM, 1995, at 2 (1996) (visited Oct. 5, 1996) <gopher://dosfan.lib.uic.edu> [hereinafter U.S. DEPARTMENT OF STATE].

3. Arlen Specter, $A$ World Court for Terrorists, N.Y. Times, July 9, 1989, 4:27.

4. Bonnie Santosus, An International Criminal Court: "Where Global Harmony Begins, " 5 TOURO INT'L L. REV. 25, 29-30 (Fall 1994).

5. United Nations Department of Public Information, Daily Highlights, Sept. 3, 1996, at 2 (visited Sept. 22, 1996)<http://www.un.org/plweb-cgi > .

6. Thalif Deen, United Nations: North-South Split Over U.N. Criminal Court, INTER PRESS SERVICE, Apr. 5, 1995, available in 1995 WL 2260180.

7. Id. 
proposed court should be given subject matter jurisdiction over international terrorism-generally, such nations are less powerful states that cannot effectively combat terrorists through independent efforts. ${ }^{8}$

Part II of this note discusses the rise in international terrorism and suggests that the United States is one of the countries most dedicated to bringing terrorists to justice. Part III then overviews the events making the establishment of a permanent international criminal court a reality and sets forth the structure of the proposed tribunal. Finally, in Part IV, the note details the debate as to whether the court, if established, should be given subject matter jurisdiction over international terrorism. That section further examines the United States' position regarding the proposed court in light of the influence it maintains over the international community.

\section{The CONTINUED THREAT OF INTERNATIONAL TERRORISM AND AMERICA'S DEDICATION TOWARD BATTLING IT}

It is unquestionable that international terrorism poses a grave threat to peace and security in the world. Former United States Secretary of State Warren Christopher stated: "President Clinton has rightly identified terrorism as one of the most important security challenges [America faces] in the wake of the Cold War." The threat posed by terrorist attacks is heightened because terrorists are now armed with weapons of mass destruction. A demonstration of this disturbing reality occurred when members of the Japanese Aum Shrinrikyo cult perpetrated a nerve gas attack on the Tokyo subway system. ${ }^{10}$

Not only are international terrorists better armed today, but the frequency of their attacks has increased. In comparing the instances of international terrorism in 1994 and 1995, the United States Department of State disclosed that the number of attacks rose from 322 to $440 .^{11}$ Additionally, international terrorist attacks against American citizens or interests increased from sixty-six in 1994 to ninety-nine in $1995 .{ }^{12}$

The United States government has not only identified global terrorism as a serious problem, but has also dedicated itself to battling the

8. $3 d$.

9. Warren Christopher, Fighting Terrorism: Challenges for Peacemakers, Address to the Washington Institute for Near East Policy Annual Soref Symposium (May 21, 1996), at 1 (visited Oct. 12, 1996) <http://www.usia.gov/topics/terror/521 speech.htm> .

10. Id.

11. U.S. DEPARTMENT OF STATE, supra note 2, at 5. Cf. U.S. DEPARTMENT OF STATE, 1995 APRIL: PATTERNS OF GLOBAL TERRORISM, 1994 (visited Oct. 5, 1996) <http://www. hri.org/docs/USSD-Terror/94/year.html > (a summary of significant acts of international terrorism in 1994 and a comparison of terroristic acts occurring in 1993 and 1994).

12. U.S. DEPARTMENT OF STATE, supra note 2 , at 5. 
phenomenon. Counter-terrorism has been identified as a top priority for the executive administration. ${ }^{13}$ Accordingly, President Bill Clinton has taken a number of steps intended to meet the threat of terrorism, including pressing for congressional legislation to increase America's capacity to fight international terrorists. ${ }^{14}$

The counter-terrorism efforts initiated by President Clinton illustrate the veracity of his statement that "[t]oday, America is more determined than ever to stand against terrorism, to fight it, to bring terrorists to answer for their crimes." ${ }^{15}$ It is, however, ironic that this declaration was made in Arlington National Cemetery at the foot of the memorial commemorating those killed in the bombing of Pan Am Flight 103, while the perpetrators of that crime continued to evade prosecution. ${ }^{16}$ The Pan Am Flight 103 bombing is a clear demonstration that unilateral actions by the United States have not been effective in combatting terrorists, and that such criminals will only be consistently brought to justice through global cooperation.

Scholars have long asserted that global terrorism must be combatted through concerted international action. ${ }^{17}$ In fact, many commentators believe that terrorism can best be combatted through the use of a permanent international criminal court. ${ }^{18}$

The United States government has also seemingly recognized that international terrorism can only be combatted effectively through global cooperation. For instance, in Sharm el-Sheikh, Egypt, President Clinton cochaired the Summit of Peacemakers, which he convened in an effort to face the growing threat of international terrorism. ${ }^{19}$ The Summit of Peacemakers brought together the leaders of a multitude of nations. ${ }^{20}$ The participating

13. The White House OfFice Of the PREss SeCRETARY, Fact SheET: COUNTERTERRORISM, at 1 (1996) (visited Oct. 12, 1996) <http://www.usia.gov/topics/terror/ factsheet $/ \mathrm{htm}>$.

14. Id.

15. U.S. DePARTMENT OF STATE, supra note 2, at 4.

16. Libya has refused extradition of the suspects accused of bombing Pan Am Flight 103 because it does not believe that its citizens will receive a fair trial in either the United States or the United Kingdom and has agreed to try them itself. The United States and the United Kingdom feel that any trial conducted by Libya will be a mere show designed to acquit the accused. Bryan F. MacPherson, An InTERnational Criminal Court: ApPlying WORLD LAW TO INDIVIDUALS 16 (1992). See also infra text accompanying notes 183-92.

17. See Ved P. Nanda, We Can Defeat International Terrorism, DENV. PosT, Feb. 5, 1995 , at D4.

18. Joel Cavicchia, The Prospects for an International Criminal Court in the 1990's, 10 DICK. J. INT'L L. 223, 233 (Winter 1992).

19. THE WHITE HOUSE OFFICE OF THE PRESS SECRETARY, supra note 13.

20. The Summit was a gathering of leaders from around the globe, including representatives of all but five Arab nations. Siona Jenkins, Summit Leaders Unite on Need to Save Damaged Peace Process, IrISH Times, Mar. 14, 1996 (visited Oct. 12, 1996) <http://www.irish-times/paper/0314/for3.html >. 
leaders ultimately decided to promote a coordinated effort to stop acts of terrorism on international levels and thus ensure that the instigators of such acts will be brought to justice. ${ }^{21}$

Some members of the United States government feel that not only is international cooperation needed to stop terrorism, but that such cooperation should come in the form of an international criminal court. For instance, for over a decade, Pennsylvania Senator Arlen Specter has advocated the creation of an international tribunal to try terrorists. Senator Specter has summarized the problems causing the growth in terrorism by explaining that terrorists are currently able to blackmail powerful countries to avoid extradition, escape prosecution, and even secure their freedom. ${ }^{22}$ Senator Specter has concluded that "[t]he fight against terrorism could be tremendously aided by [the creation of] an international court to try these international criminals." ${ }^{23}$

\section{The CREATION OF AN INTERNATIONAL CRIMINAL COURT Is MOVING TOWARD REALITY}

Senator Specter's suggestion that an international court be created to try global criminals is an idea that has existed for years. ${ }^{24}$ The first of the most recent attempts to create a permanent international criminal court was introduced by the League of Nations' Convention Against Terrorism of 1937 ("Terrorism Convention"). ${ }^{25}$ The Terrorism Convention proposed that an international tribunal be created to try the offenses that it proscribed. However, since the Terrorism Convention was first introduced, it has been ratified only by India. ${ }^{26}$

Notwithstanding the ill fate of the Terrorism Convention, the prospects for the creation of a permanent international criminal court have never been more promising than they are today. ${ }^{27}$ In April 1996, 120 countries met in Geneva and reached a consensus in favor of the establishment of a permanent international criminal court. ${ }^{28}$ Following this gathering, a committee of the

21. ISRAELI MinISTRY OF ForEIGN AFFAIRS, SUMMIT OF PEACEMAKERS: SHARM ELSHEIKH, Mar. 13, 1996, FINAL STATEMENT, at 1 (visited Oct. 12, 1996)< http://www.israelmfa.gov.il/peace/sharmsum.html $>$.

22. Specter, supra note 3, at 4:27.

23. Id.

24. Santosus, supra note 4 , at 29-30. The debate over the creation of an international criminal court can be traced to 1474 when an international tribunal was used to try Peter Von Hagebush for "crimes against God and man." Id.

25. Rupa Bhattacharyya, Establishing a Rule-of-Law International Criminal Justice System, 31 TEX. INT'L L.J. 57, 58-59 (Winter 1996).

26. Id. at 59.

27. Santosus, supra note 4 , at 31.

28. Establishing an International Criminal Court, USIA ELECTRONIC JoURNALS, May 
United Nations, the Preparatory Committee on the Establishment of an International Criminal Court ("Preparatory Committee"), began an effort to finalize the draft statute that would create the international criminal court. The committee set a goal to complete the text by April 1998 and submit it to the General Assembly of the United Nations for adoption later that year. ${ }^{29}$ The Chairman of the Preparatory Committee, Adrian Bos, commented that the fact that no country had opposed the creation of the proposed tribunal "[was] an indicator of the important progress achieved in a short period of time." 30

The United States government has endorsed the creation of a permanent international criminal court. ${ }^{31}$ However, the United States' support for the establishment of such a tribunal is only a recent development. For many years, the United States opposed the creation of the proposed court. As recently as 1992, the Judicial Conference of the United States noted that the progress of the United Nations in developing the proposed court was so insignificant that it hesitated to even comment on its feasibility at that time, stating only that the draft statute in existence left serious issues to be addressed. ${ }^{32}$ In reality, the opinion of the Judicial Conference may have been based not on the lack of progress made by the United Nations, but on the general attitude of the United States at the time, which one commentator characterized as "cautious and indifferent."

Today, however, the United States has become more open to the concept of creating a permanent international criminal court. The former United States delegate to the United Nations, James Borek, reported that President Clinton supports the creation of such a tribunal. ${ }^{34}$ Nevertheless, some are skeptical of the United States' new position, believing that the nation has become involved in the process simply to ensure the creation of

1996 (visited Oct. 12, 1996) < http://www.usis.usemb.se/journals/itps/0596/ijpe/pj4unrpt. htm $>$.

29. United Nations Department of Public Information, supra note 5.

30. Thalif Deen, United Nations: U.N. Moves Closer to a Global Criminal Court, INTER PRESS SERVICE, Aug. 22, 1996, available in 1996 WL 11624975 [hereinafter U.N. Moves Closer].

31. President Clinton has commented that "nations all around the world who value freedom and tolerance [should] establish a permanent international court to prosecute . . . serious violations of humanitarian law." David Stoelting, The Proposed International Criminal Court, N.Y.L.J., Aug. 8, 1996, at 1.

32. AdMinistrative OFFICE OF THE U.S. COURTS, REPORT OF THE JUdicial CONFERENCE OF THE U.S. ON THE FEASIBILITY OF AND THE RELATIONSHIP TO THE FED. JUDICIARY OF AN INT'L CRIM. COURT, S. REP. NO. 103-71 (1993) [hereinafter JUDICIAL CONFERENCE REPORT], reprinted in SENATE COMM. ON FOREIGN RELATIONS, 103D CONG., 1ST SESS., INTERNATIONAL CRIMINAL COURT 182 (1993) [hereinafter SENATE REPORT].

33. Timothy C. Evered, An International Criminal Court: Recent Proposals and American Concerns, 6 PACE INT'L L. REV. 121, 129 (Winter 1994).

34. Establishing an International Criminal Court, supra note 28. 
the weakest court possible: one observer suggested that the biggest obstacle to the establishment of the court to date has been the United States and asserted that the United States has now gotten involved only "because it had no choice. 'It's happening." 35 The United States can either try to shape the tribunal or end up with something that will be unacceptable to that nation's interest. ${ }^{36}$

Another possible reason for America's recent endorsement of the court may be the progress made by the Preparatory Committee in creating a more concrete draft statute detailing the structure of the proposed court and the process by which alleged criminals will be prosecuted. ${ }^{37}$ The existence of the draft may have enabled the United States to make a more informed decision as to whether such a tribunal should be created. Perhaps the United States has recognized that the drafters have created an impartial court that generally comports with the requirements of due process. ${ }^{38}$ For example, the sixty-article draft statute establishes a permanent institution consisting of judges and prosecutors separately elected by the states that are parties to the convention creating the court. ${ }^{39}$ By providing for the separate election of judges and prosecutors, the statute seeks to ensure that the prosecutorial arm of the court will be independent from the adjudicatory arm..$^{40}$ A separation of the two bodies is essential to ensure that judges will not be influenced by the prosecution.

Proceedings in the court will be initiated by the filing of a complaint by either the United Nations Security Council ${ }^{41}$ or a state that has accepted the court's jurisdiction over the alleged crime. ${ }^{42}$ Upon determining that a prima facie case exists, the prosecutor will then perform an investigation and file an indictment. ${ }^{43}$ The indictment will be reviewed by the Presidency-a

35. Tina Rosenberg, Tipping the Scales of Justice, 12 WORLD POL'Y J. 55-64 (Fall 1995) <http://worldpolicy.org/americas/wpj-f95.html> (quoting an unnamed United States administration official).

36. Id.

37. Stoelting, supra note 31 , at 1 .

38. Id. at 2.

39. Report of the International Law Commission on the Work of Its Forty-Sixth Session, U.N. GAOR, 49th Sess., Supp. No. 10, U.N. Doc. A/49/10 (1994) (Draft Statute for an International Criminal Court) [hereinafter ICC Draft].

40. Id. (art. 12).

41. Id. (art. 23).

42. Id. (art. 25). The court is intended to complement domestic courts. Nations can choose the international offenses for which they accept the jurisdiction of the court. Rosenberg, supra note 35 . This is intended to allow states who have jurisdiction over the accused an opportunity to prosecute them in their own judicial systems. Additionally, if a suspect has fled the state where the violations occurred, the jurisdiction of the court must be accepted by both the state with custody over the suspect and the state on whose territory the violation occurred. ICC Draft, supra note 39 (art. 21).

43. ICC Draft, supra note 39 (art. 27(1)). 
third branch of the court elected from among the members of the courtwhich will act as a grand jury in deciding whether there is indeed a prima facie case.$^{44}$ The Presidency may also review a decision of the prosecutor not to investigate or not to indict and can ask the prosecutor to reconsider. ${ }^{45}$

Following the review of the indictment, the person of the accused will be brought within the jurisdiction of the court. The draft statute does not require that the state of the accused accept the jurisdiction of the court before the suspect may be brought before the tribunal. ${ }^{46}$ This may seem counterintuitive since the home state of the accused may be most interested in whether the conduct of its citizen will be punished; however, the intent of the Preparatory Committee was to eliminate the difficulties associated with acquiring the consent of an overprotective home state. ${ }^{47}$ The accused's home state will still retain the opportunity to try its citizens within its own judicial system without the fear of being preempted by the international court, because the draft statute prohibits double jeopardy. ${ }^{48}$ Thus, the jurisdiction of the international court will come into effect only when the judicial powers of the home state are unused or ineffective. ${ }^{49}$

Once the court has obtained personal jurisdiction over the accused, the suspect will be tried. The draft statute creating the court adheres to basic notions of due process to ensure a fair trial of the accused. ${ }^{50}$ To protect suspects from being wrongly brought before the court, the draft statute allows the jurisdiction of the court to be challenged by interested states at the commencement of the proceeding ${ }^{51}$ and by the accused throughout the proceeding. ${ }^{52}$ In addition, the accused is entitled to a presumption of innocence. ${ }^{53}$ The draft statute also provides for the protection of the basic rights of the accused including the right to be present at trial ${ }^{54}$ and freedom from double jeopardy. ${ }^{55}$ Judgments are to be delivered in open court, ${ }^{56}$ and separate sentencing hearings are to be held to determine appropriate

44. Id. (art. 27(2)(a)).

45. Id. (art. 26(5)). However, "the ultimate decision is left to the prosecutor [because] it would be inconsistent with the independence of the prosecutor for the Presidency to direct prosecution." Bhattacharyya, supra note 25 , at 77.

46. Bhattacharyya, supra note 25 , at 85 .

47. Id.

48. ICC Draft, supra note 39 (art. 42).

49. Bhattacharyya, supra note 25 , at 86 .

50. Id.

51. ICC Draft, supra note 39 (art. 34(a)).

52. Id. (art. 34).

53. Id. (art. 40).

54. Id. (art. $37(1))$

55. Id. (art. 42).

56. Id. (art. $45(5))$. 
penalties. ${ }^{57}$ Following a trial, the statute allows appeals by both the prosecutor and the convicted individual based on procedural errors, errors of fact, errors of law, or disproportionality between the crime and the sentence. $^{58}$ Appeals are to be heard by a seven-judge Appellate Chamber. ${ }^{59}$

Thus, the protections extended by the proposed international criminal court are similar to those given to a defendant in the United States. In addition, it is apparent that the proposed tribunal is not intended to supplant the efforts made by national courts to prosecute criminals, but merely to supplement those initiatives. ${ }^{60}$ These two factors are likely to be major reasons underlying the United States' recent support for the creation of an international criminal court.

Although the Preparatory Committee has made much progress, the extent of the proposed court's subject matter jurisdiction remains an important yet unresolved issue surrounding its creation. ${ }^{61}$ The United States and many other nations argue that the court should be given subject matter jurisdiction over only genocide, crimes against humanity, and war crimes. ${ }^{62}$ The United States is opposed to granting the tribunal subject matter jurisdiction over international terrorism. ${ }^{63}$ The United States takes this position despite its recent efforts to establish international cooperation in the fight against terrorism, including convening the Summit of Peacemakers at Sharm el-Sheikh, Egypt.

Many less powerful nations favor granting the proposed international court subject matter jurisdiction over international terrorism. In general, these nations take this position because they do not have the ability to prosecute terrorists themselves. Included among these nations are: Egypt, Argentina, New Zealand, Uganda, ${ }^{64}$ Algeria, India, ${ }^{65}$ Cameroon, ${ }^{66}$ Antigua,

57. Id. (art. 46).

58. Id. (art. $48(1))$.

59. Id. (art. 9).

60. Colin Warbrick, The United Nations System: A Place for Criminal Courts?, 5 TRANSNAT'L L. \& CONTEMP. PROBS. 237, 243-44 (Fall 1995).

61. Deen, supra note 6.

62. Virginia Morris \& M.-Chrisiane Bourloyannis-Vrailas, The Work of the Sixth Committee at the Fiftieth Session of the U.N. General Assembly, 90 AM. J. INT'L L. 491, 496 (1996).

63. Katherine C. Hall, The Proposed International Criminal Court, INT'L HUM. RTS. L. UPDATE, Spring 1995, at 4 (visited Sept. 22, 1996) <http://www.aspeninst.org/dir/pol pro/JSP/IHRLspring $1995 . \mathrm{html}>$.

64. NGO COALITION FOR AN INTERNATIONAL CRIMINAL COURT, MATRIX OF COUNTRY Positions ON THE ICC FOR Nov. 1995, U.N. SiXTH CoMmITTEE MEETING (1996) (on file with author).

65. United Nations, Press Release L/2761, Preparatory Committee on Establishment of International Criminal Court Begins First Session, Mar. 25, 1996 (visited Sept. 22, 1996)<http://www.un.org > .

66. United Nations, Press Release L/2767, Laws of Particular States Should Not Be 
Barbuda, ${ }^{67}$ the Phillippines, ${ }^{68}$ Guatemala, Mali, ${ }^{69}$ Ghana, ${ }^{70}$ and the Russian Federation. ${ }^{71}$ Some of these delegations had, in fact, incorrectly presumed that the Summit of Peacemakers led by the United States had endorsed granting the proposed tribunal jurisdiction over crimes of international terrorism. $^{72}$

\section{THE AMERICAN GOVERNMENT's OPPOSITION TOWARD GRANTING THE PROPOSED INTERNATIONAL CRIMINAL COURT JURISDICTION OVER TERRORISM}

Not only does the United States' opposition to granting the international criminal court jurisdiction over global terrorism not reflect the opinion of the international community as a whole, but it also does not reflect the opinion of the nation as a whole. The American public has given some highly spirited endorsements for the creation of an international criminal court to prosecute terrorists. ${ }^{73}$ Additionally, American academics and legal professionals generally have favored granting subject matter jurisdiction over international terrorism to the proposed court. ${ }^{74}$ This group includes such notable figures as Telford Taylor, the Chief United States Prosecutor during the Nuremberg trials, who commented that establishing a permanent international tribunal to prosecute crimes like terrorism is "a thing which should be done." 75

Non-governmental organizations within the United States also favor granting an international tribunal jurisdiction over terrorist crimes. The most

Applied by International Court, Say Speakers in Preparatory Committee, Mar. 28, 1996 (visited Sept. 22, 1996)<http://www.un.org > .

67. Deen, supra note 6.

68. 44 Nations to Urge Creation of International Criminal Court, AssociATED PREss, Mar. 6, 1996, available in 1996 WL 4415133.

69. UnIted Nations, PRess Release GA/L2878, Proposed International Court Should Have Inherent Criminal Jurisdiction, Legal Committee Told, Nov. 1, 1995, at 4 (visited Sept. $25,1996)<$ http://www.un.org > .

70. Deen, supra note 6.

71. United Nations, Press Release L/2766, Terrorism Should Be a 'Core Crime' of Proposed ICC India Tells Preparatory Committee, Mar. 27, 1996 (visited Sept. 22, 1996) $<$ http://www.un.org >.

72. Id.

73. See generally Robert E. Griffin, Editorial: Court Would Deter Terror, HARRISBURG PATRIOT, Aug. 2, 1996, at A10. In the wake of the Pan Am Flight 800 tragedy, the author quoted Abraham Lincoln as saying "tragedy should inspire increased devotion to ideals." Id. Furthermore, the author concluded that "[t]he creation of an International Criminal Court is such an ideal." Id.

74. See generally Santosus, supra note 4 , at 28.

75. Linda Maguire, An Interview With Telford Taylor, 18 FALL FLETCHER F. WORLD AFF. 1,3 (1994). 
notable example is the Non-Governmental Organization Coalition for an International Court ("Coalition"), which has brought together a broad variety of non-governmental organizations for the purpose of advocating "an effective and just International Criminal Court." ${ }^{76}$ Some of the organizations involved in the Coalition include: Amnesty International, DePaul Institute for Human Rights, International Human Rights Law Group, and the United Nations Association-USA. ${ }^{n}$ Bill Pace, the organizer of the Coalition, stated that terrorist incidents like the bombing of Pan Am Flight 103 "are excellent examples of the kinds of crimes requiring an international criminal court."78

Regardless of the opinions expressed by these groups, the United States government generally does not favor granting an international criminal court jurisdiction over global terrorism. ${ }^{79}$ For better or worse, the opinion of the United States government is the only one that truly matters, because ultimately its desires, along with those of other involved nations, will shape the structure of the proposed court. The United States government has, at various times, expressed support for granting an international criminal court jurisdiction over terroristic crimes. For instance, the Omnibus Security and Terrorism Act of 1986 declared that the President should contemplate "the possibility of eventually establishing an international tribunal for prosecuting terrorists." 80

In addition, Senator Arlen Specter has consistently called for the creation of an international criminal court to address global terrorism. ${ }^{81}$ Likewise, House Banking Chairman Allen Leach asked the Clinton administration to assume a leadership role in the global fight against

76. NGO COALTION FOR AN INTERNATIONAL CRMMINAL COURT, INFORMATION SHEET, (1996) (visited Sept. 22, 1996) < gopher://gopher.igc.apc.org;7030/0./icc/ciccflyr.txt>.

77. Id.

78. U.N. Moves Closer, supra note 30.

79. John M. Goshko, U.N. Moving Toward Creation of Criminal Court; But Advocates Fear Severe Limits, Backed by U.S., Will be Imposed on Its Independence, WASH. POST, Apr. 21, 1996, at A27. See also Report of the International Law Commission on the Work of Its Forty-Sixth Session, U.N. GAOR, 49th Sess., Agenda Item 137, at 13, U.N. Doc. A/C.6/49/SR.17 (1994) (statement of Conrad K. Harper, Legal Advisor, U.S. Department of State). The United States does not clearly see the need for an international criminal court in cases other than genocide, crimes against humanity and war crimes. Id.

80. Cavicchia, supra note 18, at 230-31 (quoting Omnibus Diplomatic Security and Terrorism Act of 1986, Pub. L. No. 99-399, 1986 U.S.C.C.A.N. (100 Stat.) 853).

81. See 141 CONG. REC. S16652-01 (daily ed. Nov. 3, 1995) (statement of Sen. Specter). "For more than a decade . . . I have urged the formation of an international criminal court to deal with crimes such as hostage taking, terrorism and drug dealing where we find that there are people in custody who [the custodial nation] will not extradite to the United States ...." Id. See also 140 CONG. REC. S11384-01 (daily ed. Aug. 12, 1994) (statement of Sen. Specter). "Terrorism remains an enormous problem internationally. . . . One area on which we have not had . . . progress is in the establishment of an international criminal court which I have spoken about many times during my 14 years in this body . . . " Id. 
terrorism by working towards the establishment of an international criminal court. $^{82}$ However, the urgings of Specter and Leach have not received the support of either the Republican or Democrat congressional factions.

Thus, the prevailing opinion of the United States government today is that the proposed international criminal court should not have jurisdiction over international terrorism. While the United States is only one country within the United Nations system, its position is worthy of careful analysis because America has a recognized ability to influence other nations. Illustrating this proposition is former Secretary of State Warren Christopher's statement that the responsibility of the United States in the Middle East is "[t]o use our influence to stop the suffering of innocent civilians" who continue to be victimized by terrorist attacks. ${ }^{83}$ It follows that if an international criminal court would alleviate the suffering caused by global terrorism, then it might also be the responsibility of the United States to use its influence to see that the proposed tribunal is granted jurisdiction over that crime.

The reasons behind the United States' opposition to granting the proposed court jurisdiction over terrorism are varied. Some objections are not based on the specific qualities of the crime of terrorism, but on concerns about the court in general. Such concerns have created a desire on the part of the American government to limit the court's jurisdiction to as few crimes as possible and thus exclude terrorism. ${ }^{84}$ Among these concerns are: (1) the sovereignty of the United States will be invaded by the creation of a strong international court with the ability to try global terrorism; ${ }^{85}(2)$ the tribunal could become a highly politicized body where suspects will be tried by biased judges hailing from enemy nations; ${ }^{36}$ and (3) the international criminal court will not afford defendants the same due process protections given to suspects tried in courts of the United States. ${ }^{87}$

The United States also has several objections to granting the proposed court jurisdiction over international terrorism that are specifically related to the nature of that crime. Among these concerns are: (1) there is no international law under which terrorists may be prosecuted (i.e., the doctrine of nullum crimen sine lege); ${ }^{88}$ (2) granting the proposed tribunal jurisdiction over terrorism will overburden the court and increase disagreement

82. Leach Seeks International Court to Battle Terrorism, CoNG. DAIL Y A.M., Apr. 27, 1995, available in 1995 WL 10434303.

83. Christopher, supra note 9.

84. See supra text accompanying notes 34-36.

85. See infra text accompanying notes 91-106.

86. See infra text accompanying notes 107-25.

87. See infra text accompanying notes 126-39.

88. See infra text accompanying notes $140-49$. 
surrounding its establishment causing further delays in implementation; ${ }^{89}$ and (3) creating a world court with jurisdiction over terrorism would disrupt the workings of the already existing system of treaties that has allowed the United States to effectively deal with international terrorists. ${ }^{90}$

\section{A. American Concerns about the Proposed International Criminal Court Itself}

The United States' first objections to the court are general concerns that have prompted a call for a weak court with jurisdiction over only genocide, war crimes, and crimes against humanity. One such concern is that national sovereignty will be invaded by a permanent court with jurisdiction over crimes like global terrorism.91 The refusal of states to surrender sovereignty is perhaps the oldest problem associated with the establishment of an international criminal court.

In 1899, Nicholas II of Russia convened twenty-six sovereign nations at the First Hague Peace Conference to discuss disarmament. ${ }^{92}$ The goal of the conference was "to create an international court with compulsory jurisdiction which would transcend national borders." 93 The Conference succeeded only in establishing the Permanent Court of Arbitration that never functioned on a permanent basis and tried only approximately twenty cases in eighty years. ${ }^{94}$ The failure of the Permanent Court of Arbitration resulted from the unwillingness of sovereign nations to be bound by an impartial international body. ${ }^{95}$ The United States, in fact, expressly reserved the power to resolve any purely American issues. ${ }^{96}$

In the following years, many developments resulted in an increased willingness on the part of nations to sacrifice a fraction of their independence to ensure that international criminals would be prosecuted. This increase in global determination to prosecute international criminals was first displayed at the Nuremberg and Tokyo trials. ${ }^{97}$ Later, the European Court of Human Rights and the Inter-American Court of Human Rights were established in 1950 and 1975, respectively, for the purpose of holding governments accountable for their own nationals' violations of the European Convention

89. See infra text accompanying notes $150-62$.

90. See infra text accompanying notes 163-221.

91. Daniel B. Pickard, Security Council Resolution 808: A Step Toward a Permanent International Court for the Prosecution of Intermational Crimes and Human Rights Violations, 25 GOLDEN GATE U. L. REV. 435, 443-44 (1995).

92. Id. at 443.

93. Id.

94. Id. at $443-44$.

95. Id. at 444 .

96. Id.

97. Id. at 454 . 
on Human Rights. ${ }^{98}$ Although the Convention did not endow the courts with mandatory jurisdiction, several nations voluntarily submitted to the jurisdiction of these international tribunals, thereby surrendering a significant portion of their sovereignty to ensure the protection and enforcement of human rights by an international court of law. ${ }^{99}$

Today, nations have become even more dedicated to establishing a permanent tribunal to prosecute international criminals. The United States is one of the countries committed to this notion. ${ }^{100}$ Nevertheless, because counter-terrorism is such a high priority for the United States government, ${ }^{101}$ it might fear that relinquishing authority as a sovereign to prosecute terrorists to a newly formed tribunal would not be in the best interests of its citizenry.

However, the draft statute establishing the proposed court attempts to address such sovereignty issues in its preamble by stating that the "court is intended to be complementary to national criminal justice systems in such cases where trial procedures may not be available or may be ineffective." 102 The statute goes on to deal specifically with sovereignty concerns by allowing states to choose the jurisdiction they wish to confer on the tribunal. Article 22 of the statute allows nations to accept the jurisdiction of the court for crimes of their choice, ${ }^{103}$ and gives them the right later to deny the courts' jurisdiction over the same crimes by giving a notice six months in advance. ${ }^{104}$ In addition, the court will allow states to refer cases to it on an ad hoc basis without permanently submitting to its jurisdiction. ${ }^{105}$

Article 22 thus allows a nation to "relinquish jurisdiction [to the court] over certain offenders and still remain sovereign."106 For instance, if the court were given the authority to try terrorism cases, the United States could grant it jurisdiction over the individuals accused of bombing Pan Am Flight 103. This would provide the families of the victims with the knowledge that the perpetrators of the crime had been brought to justice without interfering with the sovereign ability of the United States government to prosecute any subsequently accused terrorists.

American officials also oppose giving the proposed international criminal court jurisdiction over causes of action other than genocide, war crimes, and crimes against humanity for fear that the tribunal might become a politicized body where the accused will be tried by biased judges hailing

98. Id. at 456.

99. Id.

100. See supra text accompanying note 34 .

101. See supra text accompanying note 13 .

102. ICC Draft, supra note 39 (Annex).

103. Id. (art. 22(1)(b)).

104. Id. (art. 22(3)).

105. Id. (art. 22(2)).

106. Santosus, supra note 4 , at 40. 
from enemy nations. ${ }^{107}$ These fears ignore the fact that the current extradition system does not prevent defendants from being tried before biased foreign nationals. In the United States, "extradition hearings are more like probable cause hearings than determinations of guilt or innocence and need not even be carried out before an Article III judge." 108 Once it has been demonstrated that the accused is the individual sought and that there is reason to believe that he committed an offense within the scope of an extradition treaty, the suspect will be extradited. ${ }^{109}$ This rule applies even when the defendant is a United States citizen who alleges that he will be tortured or killed should he be extradited. ${ }^{110}$

The United States courts also will not consider the adequacy of the judicial procedure that the defendant will receive upon extradition; it is bound to assume the trial will be fair due to the existence of an extradition treaty. ${ }^{111}$ These procedures, employed under the current system, often cause accused terrorists to face biased or prejudicial proceedings. For example, although the United Kingdom is reputed as having one of the fairest legal systems in the world, it was recently revealed that its courts wrongly convicted eighteen suspected IRA terrorists. ${ }^{112}$ In one case, several individuals collectively known as the Guilford Four were released from prison after it was determined that their confessions had been coerced through severe beatings. ${ }^{113}$ It was also found that the investigating officers committed perjury and withheld exculpatory evidence in order to obtain their convictions. In addition, the government of the United Kingdom had enacted legislation to relax procedural safeguards in the trials of such suspected terrorists in Northern Ireland. ${ }^{114}$

Throughout this time, the United States continued to extradite suspected IRA terrorists to the United Kingdom. ${ }^{115}$ In fact, in 1985 the

107. SENATE REPORT, supra note 32, at 19 (statement of Sen. Helms). “[J]udges would come from 'States Members of the United Nations as well as non-member States maintaining permanent observer missions at United Nations headquarters.' . . . [T] he General Assembly [of the United Nations] contains all the world's major dictatorships including Syria, Libya, Cuba and North Korea just to name a few." Id.

108. Paul D. Marquardt, Law Without Borders: The Constitutionality of an International Criminal Court, 33 Colum. J. TRanSNat'L L. 73, 108 (1995).

109. Id.

110. Id. at 108-9.

111. Id. at 109.

112. MACPHERSON, supra note 16 , at 13.

113. Id. at 13-14.

114. Id. at 14.

115. See In re Smyth, 820 F. Supp. 498,502 (N.D. Cal. 1993). Smyth was charged by the United Kingdom with murdering a prison guard in an escape attempt. Smyth was not allowed to challenge the general fairness of the court system in which he would be tried. In addition, the accused could not present evidence that he would be subject to restraints on his liberty even if he were released from prison, nor could he attempt to demonstrate risk of 
American government entered into a revised extradition treaty with the United Kingdom prohibiting those accused of violent crimes from availing themselves of the political offense exception (an extradition treaty exception whereby a nation may opt not to extradite those accused of political offenses). ${ }^{116}$ The revision was accepted due to the respect the United States government had for the judicial system of the United Kingdom and the resulting assumption that these suspects would receive a fair trial. ${ }^{117}$

The draft statute establishing the proposed international criminal court contains safeguards to ensure that those trying the accused will not be the biased citizens of enemy nations. First, the statute allows each state to nominate for election as judges two parties who must be of separate nationalities. ${ }^{118}$ Next, the states together will elect eighteen judges, none of whom may be of the same nationality. ${ }^{119}$ Upon election, judges must perform their functions independently. This means that they may not be members of the legislative or the executive branches of any state. ${ }^{120}$ The accused would be tried in the presence of five of these judges, none of whom could be from the nation of either the suspect or the complaining party. ${ }^{121}$ In addition, the defendant would have to be convicted or acquitted by a majority of these judges. ${ }^{122}$

Thus, in comparing the draft statute and the United States' past experience, it is clear that the draft statute creates a more impartial tribunal than those of countries to which the United States currently extradites suspects. The Judicial Conference of the United States admitted this even when the American government was skeptical that an international court was feasible at all. ${ }^{23}$ The Judicial Conference stated that one "possible benefit [of the proposed tribunal] is that defendants might receive a fairer trial in an

assassination. However, since he had already been convicted in that court system and imprisoned, he could introduce irregularities in his previous trial. Id. at 502-3. The conviction of the defendant for attempted murder precluded him from asserting the "political offense" defense pursuant to the revised extradition treaty between the United States and the United Kingdom. Id. at 500. Cf. In re Doherty, 599 F. Supp. 270, 276 (S.D.N.Y. 1984). The extradition request for Doherty was made before the "political offense" defense was precluded. The court held that the murder of a British army captain by a member of the Irish Republican Army was a political offense. Id.

116. MACPherson, supra note 16, at 14 (citing Michael P. Scharf, The Jury is Still Out on the Need for an International Criminal Court, 1991 DUKE J. COMP. \& INT'L L. 135, 153 (1991)). See also supra note 115.

117. MACPHERSON, supra note 16 , at 14 n.21.

118. ICC Draft, supra note 39 (art. 6(2)).

119. Id. (art. 6(4)).

120. Id. (art. 10(2)).

121. Id. (art. 9(7)).

122. Id. (art. 45(2)).

123. See supra text accompanying notes $32-33$. 
international tribunal than in a politically-charged forum state."124 The Judicial Conference then specifically cited the courts established by the United Kingdom to try suspected terrorists as one example where "[a]n international court might provide a more neutral forum . . . "125

Several members of the American government also want to limit the jurisdiction of the proposed tribunal because they are concerned that it will not give suspects the same due process guarantees that they would receive in the United States. ${ }^{126}$ However, the international tribunal would be more analogous to a foreign jurisdiction than to an instrumentality of the United States. The international criminal court would operate under its own authority and apply its own laws; thus, the judicial power of the United States would in no way be invoked. ${ }^{127}$ Since the proposed tribunal should not be considered a court of the United States, its protections should be compared to those of a foreign forum to which America currently extradites suspects.

When the tribunal is viewed as a foreign court to which the United States will merely extradite defendants, the protection of individual rights it affords is more than sufficient under a due process analysis. Under the American system of extradition, once it is determined that the accused is the person sought and that there is reason to believe he committed the crime, he will be extradited even if it is alleged that the trial will be unfair or that the accused will be tortured or killed. ${ }^{128}$ Against this background, the proposed international criminal court clearly provides an acceptable level of protection of basic human rights.

The draft statute establishing the structure of the proposed international criminal court contains a number of safeguards aimed at protecting individual rights. For instance, Article 42 protects the accused from double jeopardy. ${ }^{129}$ Additionally, the penalties provided for under Article 47 would not violate the prohibition, found in the Eighth Amendment to the United States Constitution, against cruel and unusual punishment. ${ }^{130}$ Furthermore,

124. JudiCIAL CONFERENCE REPORT, supra note 32, at 43.

125. Id.

126. Id. at 45 .

127. Marquardt, supra note 108 , at 105.

128. Id. at 108-9; see also supra text accompanying notes 107-10. See also Escobedo v. United States, 623 F.2d 1098, 1107 (5th Cir. 1980). American citizens attempted to kidnap the Cuban Consul in Merida, Mexico. During the attempt, an associate of the Consul was shot and killed. One American suspect, Escobedo, alleged that he would be tortured or killed upon extradition to Mexico. The Fifth Circuit Court of Appeals affirmed his extradition regardless, noting that such issues are for the executive branch to consider when entering into extradition treaties. Id.

129. ICC Draft, supra note 39 (art. 42).

130. Id. (art. 47). The maximum penalty provided for under Article 47 is life imprisonment. No person convicted of any crime may be sentenced to death. Furthermore, 
Article 41 provides the accused with the right to a speedy trial, ${ }^{131}$ freedom from self-incrimination, ${ }^{132}$ the right to counsel, ${ }^{133}$ and the right to compel the attendance of witnesses. ${ }^{134}$ As in United States courts, the accused will also be "presumed innocent until proven guilty in accordance with the law." 135

It is true that the accused will not receive a jury trial, but will be judged by a panel of five judges who will acquit or convict by majority vote. ${ }^{136}$ However, the peculiar status of the tribunal as an international court must be kept in mind. Judge John J. Parker observed that "[the judges would be] better qualified than a jury could possibly be to pass upon the issues which would be presented to a court trying the complicated sort of cases which would be presented to an international criminal court."137 Additionally, one commentator recalled that the general reasoning behind the creation of the United States Constitution was to ensure the supremacy of laws. ${ }^{138}$ An international tribunal could help bring to justice international terrorists who are currently able to seek refuge in nations that distrust the judicial system of the victimized country; such current practices violate the concept of supremacy of laws. ${ }^{139}$

\section{B. American Concerns about the Specific Nature of the Crime of Terrorism}

The United States objects to granting the proposed court jurisdiction over international terrorism not simply on the basis of its desire to create a weak tribunal, but also on the basis of the specific nature of the crime. One such protest is that no international law exists under which terrorists may be prosecuted. ${ }^{140}$ This objection is commonly known as the doctrine of nullum crimen sine lege, which means there is no crime without law. Finding law under which to prosecute terrorists presents an especially difficult problem

in determining the length of the sentence the court will consider the law of: the state of the accused, the state where the crime was committed, and the state that had custody over the accused. Id.

131. Id. (art. $41(\mathrm{c}))$.

132. Id. (art. $41(\mathrm{~g}))$.

133. Id. (art. 41(d)).

134. Id. (art. $41(\mathrm{e}))$.

135. ld. (art. 40).

136. Id. (art. 45).

137. Ilia B. Levitine, Constitutional Aspects of an International Criminal Court, 9 N.Y. INT'L L. REV. 27, 38 (1996) (quoting John J. Parker, An International Criminal Court: The Case for Its Adoption, 38 A.B.A. 641, 643 (1952)).

138. Id. at 47.

139. Id. Cf. JUDICIAL CONFERENCE REPORT, supra note 32, at 47 . "[T]rial by jury is fundamental to our system. U.S. Const. art. III, $\$ 2$. However, none of the draft statutes . . provides for a jury trial even in the most serious offenses." Id.

140. Pickard, supra note 91 , at $442-43$. 
because one man's terrorist is often considered to be another man's freedom fighter. ${ }^{141}$

While it is true that there is no comprehensive international criminal code, criminal law does exist that proscribes acts of global terrorism. The United Nations Conventions provide concrete bodies of substantive international law under which the proposed court could prosecute terrorists. For instance, the Convention on the Prevention and Punishment of Crimes Against Internationally Protected Persons provides laws prohibiting terrorist attacks on diplomats. ${ }^{142}$ The Convention on Offenses and Certain Other Acts Committed on Board Aircraft is a substantive body of law under which aircraft highjackers and bombers could be prosecuted. ${ }^{143}$ In addition, terrorists charged with taking hostages could be prosecuted under the International Convention Against Taking of Hostages. ${ }^{144}$

Although past efforts of the United Nations to adopt an international criminal code have failed, a draft of such a code exists today. ${ }^{145}$ In recent years, "[s]cholars and members of the United Nations have made substantial progress in drafting an international criminal code." 146 The crimes that are to be proscribed by the code include terrorism and aircraft highjacking. ${ }^{147}$

141. Specter, supra note 3. Senator Specter states that: "[a] narrow definition of terrorism, limited to offenses such as hijacking and hostage-taking, could avoid the political quagmire of distinguishing between a terrorist and a freedom fighter." Id.

142. Convention on the Prevention and Punishment of Crimes Against Internationally Protected Persons (New York Convention), Dec. 14, 1973, 1035 U.N.T.S. 167.

143. Convention on Offenses and Certain Other Acts Committed on Board Aircraft (Tokyo Highjacking Convention), Sept. 14, 1996, 704 U.N.T.S. 219. This Convention could have been used by an international tribunal to try Mohammad Hamadei, who in 1985 highjacked TWA Flight 847 and killed an American in the process. Hamadei was apprehended by German authorities, and the United States sought extradition. During this debate, terrorists kidnapped two German businessmen in an effort to block his extradition. In the end, Hamadei was tried in Germany and received a life sentence. Had there been an international criminal tribunal to try Hamadei, perhaps the kidnapping of the two German civilians would have been prevented. MACPHERSON, supra note 16 , at 18 .

144. International Convention Against Taking of Hostages, Dec. 18, 1979, G.A. Res. 146, U.N. GAOR, 34th Sess. (1979). The terrorists who kidnapped the two German businessmen in an effort to manipulate the German government could be prosecuted under this convention. See supra note 143. The Convention on the Prevention of Crimes Against Internationally Protected Persons (New York Convention), Convention on Offenses and Certain Other Acts Committed on Board Aircraft (Tokyo Highjacking Convention), and the International Convention Against Taking of Hostages are collectively referred to throughout the text as the Terrorism Conventions.

145. Pickard, supra note 91 , at 443 . In 1954, a draft code of offenses entitled the Code of Offenses Against the Peace and Security of Mankind was submitted to the United Nations. Since then that code has been reintroduced numerous times but has never been adopted. Id.

146. Id. at 452.

147. Id. (citing M. Cherif Bassiouni, INTERNATIONAL CRIMINAL LAW: A DRAFT InTERNATIONAL CRIMINAL CODE 52-106 (1980)). 
Although the draft code has not been ratified to date, the United Nations has made great strides in developing it.

The fact that the prospects for the completion of an international criminal code have improved does not mean that the international criminal court should wait for its ratification before assuming jurisdiction over terrorism. The existing conventions proscribing various methods employed by terrorists to threaten global security create a sufficiently concrete body of substantive international law to allow violators to be immediately prosecuted by the proposed tribunal.

The aforementioned Terrorism Conventions do not cover all of the acts of terrorism that are proscribed in the United States. However, the proposed tribunal is intended to only supplement national criminal justice systems in cases where trials in those states are unavailable or ineffective. ${ }^{148}$ Therefore, the United States could continue to prosecute terroristic conduct prohibited by its own laws in American courts. In fact, the United States could even prosecute offenses falling under the conventions in its own courts if it decides not to accept the jurisdiction of the tribunal with respect to those crimes or that particular offense. ${ }^{149}$ The United States, however, should support granting the proposed court jurisdiction over the crimes proscribed by the Terrorism Conventions even if it does not intend to avail itself of that jurisdiction; such support would aid less powerful nations that are unable to effectively prosecute terrorists themselves.

The United States also seeks to exclude global terrorism from the jurisdiction of the proposed court because of concerns that allowing the tribunal to try crimes other than genocide, war crimes, and crimes against humanity will overburden it and possibly stall its creation. ${ }^{150}$ However, giving the proposed tribunal jurisdiction over the offenses falling under the Terrorism Conventions will not overburden the court. In 1995, there were 440 acts of international terrorism. ${ }^{151}$ Of the 440 acts of international terrorism, 272 were low-level arson attacks on property occurring in Germany and Turkey orchestrated by the Kurdistan Workers' Party (PKK). ${ }^{152}$ These arson assaults are not proscribed by any of the Terrorism Conventions and thus could not be brought before the proposed court. Of the remaining 168 acts of international terrorism occurring in 1995 , only about thirty major incidents involved acts prohibited by the Terrorism Conventions. ${ }^{153}$ Assuming that all of these incidents would be brought before

148. ICC Draft, supra note 39 (Annex).

149. See supra text accompanying notes 102-06.

150. Terrorism Should Be a 'Core Crime' of the Proposed ICC India Tells Preparatory Committee, supra note 71. See also Stoelting, supra note 31.

151. U.S. DEPARTMENT OF STATE, supra note 2, at 5.

152. Id. at 6.

153. Id. 
the tribunal, it is unlikely that thirty cases would overburden a court of eighteen judges sitting in five-judge panels.

Concededly, the court would also be responsible for the adjudication of cases involving crimes against humanity, genocide; and war crimes. However, the possibility that all of the cases involving major acts of international terrorism would be brought before the court is slim. The proposed tribunal is intended only to supplement national efforts to prosecute terrorists, not replace them. ${ }^{154}$ Many nations, like the United States, will elect to prosecute terrorists in their own courts whenever they have the opportunity to do so. ${ }^{155}$ Thus, of the thirty cases that the tribunal could try, in reality it will only receive cases where the complaining nation is unable to prosecute the defendant itself. These cases would be those in which the nation with custody over the defendant refuses extradition to the complaining state, or where the victimized nation is afraid to prosecute the suspect. These are the exact types of situations that exemplify the need for the creation of an international criminal court.

Some speculate that the proposed court is actually unlikely to receive many cases involving genocide, war crimes, or crimes against humanity. ${ }^{156}$ Such crimes are typically committed or endorsed by those who control the actions of a nation. Only through defeat or disgrace will criminals of this caliber be handed over willingly by the governments they control. ${ }^{157}$ Thus, in a majority of these situations, in order to prosecute the offender, the court would have to intervene against the wishes of the national government. This realization led one commentator to conclude that these types of cases "are the least likely to reach trial before an international court." 158

Thus, the real danger may exist not in the creation of an overburdened tribunal, but in the creation of an illegitimate court that never actually tries cases. ${ }^{159}$ "A weak and inactive court may undermine respect for international law and any deterrent effect that the prospect of criminal responsibility might have." 160 Giving the proposed tribunal jurisdiction over international terrorism would allow it to preside over several cases each year concerning problems that could actually be resolved. Therefore, jurisdiction over crimes such as terrorism is exactly what the court needs to help it build

154. ICC Draft, supra note 39 (Annex).

155. Under the draft statute establishing the proposed court, a nation could prosecute particular offenses even though they have consented to granting the court jurisdiction over that crime. Id. (art. 22). Countries such as the United States will likely desire to try some particular offenses in their own judicial systems for a number of reasons, including the fact that the proposed tribunal may not sentence convicted defendants to death. Id. (art. 47).

156. Marquardt, supra note 108 , at 96.

157. Id.

158. Id.

159. Id. at 139.

160. Id. 
a positive reputation and save it from being useless.

World leaders should also avoid granting the court jurisdiction over only those offenses that have not been contested (i.e., genocide, war crimes, and crimes against humanity) simply to avoid further debate surrounding its creation. Several states have expressed concerns that adding crimes like terrorism will cause further delays in the creation of the tribunal. ${ }^{161}$ However, as stated by David Sheffer, legal adviser to United States Ambassador Richard Dicker, the objective of the countries involved should be "to get it right and now [rather than] to rush to create a court which in the end will be weak, ineffective and not joined by many countries in the world:" 162

Perhaps the most vigorously asserted objection to granting the proposed tribunal jurisdiction over international terrorism is that such jurisdiction would disrupt the workings of already-existing treaties that have proven to be an effective means of dealing with terrorists. ${ }^{163}$ However, this is an isolationist contention that ignores the fact that many smaller nations cannot deal with terrorists themselves. ${ }^{164}$ Additionally, the multi-national treaties that the United States worries will be disrupted have weaknesses and do not ensure that even America, as powerful as it is, will be able to prosecute terrorists. ${ }^{165}$ In many cases the United States has been forced to extend, through Supreme Court decisions, its jurisdiction to apprehend a terrorist who otherwise could not have been prosecuted under the applicable treaty. ${ }^{166}$ These situations have caused many allies to become infuriated with the American government, because the United States has often resorted to

161. Laws of Particular States Should Not Be Applied by International Court, Say Speakers in Preparatory Committee, supra note 66. Japan believes that any discussion regarding the jurisdiction of the proposed court over terrorism will delay the court's establishment. Id. See also Proposed International Court Should Have Inherent Criminal Jurisdiction, Legal Committee Told, supra note 69. Jamison Borek of the United States feels that there is not enough support to include terrorism within the jurisdiction of the court. Id.

162. David Sheffer, Opposing Sides Discuss U.S. Participation in Tribunal (National Public Radio, Aug. 27, 1995), available in Westlaw, 1995 WL 2916142.

163. See SENATE REPORT, supra note 32, at 23 (statement of Edwin D. Williamson). "I fear that the alternative of a permanent court could undermine the efficacy of the prosecute or extradite approach and impair efforts to foster domestic administration of justice reforms in other countries." Id. See also Evered, supra note 33, at 133. The United States has expressed concern that "the proposed court might disrupt or detract from the existing mechanisms of international cooperation." Id. See also John B. Anderson, An International Criminal Court-An Emerging Idea, 15 Nova L. REV. 433 (1991). Anderson notes that "the argument can be made that such a court is unnecessary because the United States has already demonstrated the capacity and will to deal by statute with such matters as terrorism and hostage taking." Id. at 439.

164. See infra text accompanying notes $168-81$.

165. See infra text accompanying notes $182-97$.

166. See infra text accompanying notes 198-208. 
economic sanctions to punish terrorists when treaties are ineffective. ${ }^{167}$ Such sanctions are not always effective and frequently cause uninvolved states to resent the United States government.

The contention of the United States that the proposed court should not be given jurisdiction over terrorism because it can effectively deal with terrorists itself is an isolationist argument. This contention ignores the fact that smaller countries have not been as successful as America in the war against terrorism. Many small states lack the resources to bring terrorists to justice ${ }^{168}$ because the criminals themselves are often better armed than the nations' security forces. ${ }^{169}$ Lionel Hurst, the United Nations delegate from Antigua and Barbuda, noted that weaker nations are forced into an awkward situation when prosecuting terrorists, because they must "handle [the] criminals carefully, because [the criminals] are citizens of large countries."170 The United States generally takes pride in protecting smaller countries and then-United Nations Ambassador Madeleine K. Albright at one time even criticized some members of Congress for espousing isolationist views. ${ }^{171}$

Colombia is an example of a smaller country that has been unable to bring terrorists and other criminals to justice. Colombia cannot try or extradite terrorists and drug-traffickers due to risks of adverse political consequences or violent repercussions at home. ${ }^{172}$ Narco-terrorists have murdered hundreds of law enforcement officers, judges, and political leaders, generating an atmosphere wherein bringing drug-traffickers and terrorists to justice is life-threatening. ${ }^{173}$ In 1995, Colombia recorded seventy-six international terrorist incidents, the highest number in Latin America. ${ }^{174}$ Among the many killed by Colombian terrorists in 1995 were two American missionaries who had been held hostage by the Revolutionary Armed Forces of Colombia since 1994. ${ }^{175}$ The same group later attacked a police counter-narcotics base, killing six and injuring twenty-nine police officers. ${ }^{176}$

Colombia is not only unable to prosecute terrorists itself, but also it cannot extradite these criminals to the United States due to bitterness and resentment on the part of the Colombian population toward the American

167. See infra text accompanying notes 209-21.

168. U.S. Should Back Concept of an International Criminal Court, DENV. POST, Apr. 20,1996 , at B7.

169. Deen, supra note 6.

170. Id.

171. Madeleine K. Albright, International Law Approaches the Twenty-First Century: A U.S. Perspective on Enforcement, 18 FordhaM INT'L L.J. 1595, 1599 (1995).

172. SENATE REPORT, supra note 32, at 10.

173. Id.

174. U.S. DEPARTMENT OF STATE, supra note 2, at 18.

175. Id. at 5.

176. Id. at 17 . 
government. ${ }^{17}$ Unless an alternative such as an international criminal court is made available to the government of Colombia, drug-traffickers, paramilitary squads, and common criminals will continue to commit scores of terrorist acts with complete impunity.

Countries whose security forces are too weak to apprehend international terrorists are often forced to resort to criminal acts themselves. In October 1995, Palestine Islamic Jihad (P.I.J.) leader Fathi Shaqaqi was assassinated. ${ }^{178}$ The P.I.J. is a group committed to the destruction of Israel through holy war and is responsible for numerous suicide attacks against Israeli targets in the West Bank, the Gaza Strip, and Israel. ${ }^{179}$ The group assumed that Israel ordered the assassination of its leader as retribution, and symbolized post-assassination support for their cause with a poster that depicted a burning Israeli school bus. ${ }^{180}$ One commentator noted that although assassination is an illegal self-help remedy under international law, in the absence of a global authority to enforce the rules against terrorism, nations seeking justice are forced to rely on it and other self-help methods. ${ }^{181}$

Aside from ignoring the needs of smaller countries, the United States may overstate its contention that it can successfully combat terrorists within the existing system of extradition treaties. ${ }^{182}$ A situation vividly demonstrating the need for an international criminal court is the failure of the United States to apprehend and try the terrorists responsible for bombing Pan Am Flight 103 over Lockerbie, Scotland, on December 21, 1988. ${ }^{183}$ In November 1991, two Libyan intelligence agents were indicted for destroying the aircraft. ${ }^{184}$ However, Libya refused to extradite the suspects to either the United States or the United Kingdom because of doubts that its citizens would receive a fair trial in those forums. ${ }^{185}$ Libya instead offered to try the suspects itself, but British and American officials were concerned that the

177. MACPHERSON, supra note 16 , at 15 . "Colombia was for a time extraditing accused drug-traffickers to the United States for trial. This was in violation of its Constitution, but was permissible under a declaration of a state of emergency. Such extraditions were not politically popular and are no longer permitted." Id. at 15 n.24.

178. U.S. DEPARTMENT OF STATE, supra note 2, at 26.

179. Id. at 52-53.

180. Louis Rene Beres, An Enemy of Mankind, Jerusalem Post, Nov. 3, 1995, at 5.

181. Id.

182. See, e.g., Nanda, supra note 17, at D4. The author, who serves as the Director of the International Legal Studies Program at the Denver University College of Law, notes that the United States has adopted comprehensive legislation on the subject of terrorism and entered into numerous bilateral agreements with other nations. He suggests further that " $[w]$ hat has been done is still not enough, and no effort should be spared to meet this tremendous challenge." Id.

183. MACPHERSON, supra note 16, at 16 (quoting WASH. POST, Nov. 16, 1991, at A23).

184. U.S. DEPARTMENT OF STATE, supra note 2, at 29.

185. MACPHERSON, supra note 16 , at 16. 
trial would be a mere show designed to acquit the defendants. ${ }^{186}$ Russian Foreign Minister Andrei Kozyrev suggested that Libya offer the defendants to the United Nations for trial. ${ }^{187}$ Soon afterward, the Libyan government agreed to send the case to "neutral international committees of inquiry or to the International Court of Justice." 188 However, since an international criminal court has not yet come into existence, the suspects indicted for the bombing remain free. One scholar has expressed surprise that the United States maintains that states should remain solely responsible for prosecuting terrorists in light of its experience with the Libyan terrorists. ${ }^{189}$

Edwin D. Williamson, a former legal advisor to the U.S. Secretary of State, argued that pushing for the establishment of an international criminal tribunal to try the Flight 103 bombers "would have played into the hands of the Libyans." 190 However, a verdict against the suspects from an international court would hurt Libya far more than would a guilty verdict from an American court because many of Libya's allies believe that the United States has prejudged the defendants. ${ }^{191}$ Furthermore, if the Libyan offer to turn the accused individuals over to an international tribunal were a mere sham, Libya's hypocrisy would be demonstrated to the entire world. ${ }^{192}$ Instead, as it stands, the international community can only impose sanctions on the Libyan government when that country either complies with the extradition requests of the United States and the United Kingdom, or when an international criminal court is created.

A second situation demonstrating America's inability to effectively prosecute terrorists under the existing system is its attempt to apprehend and try Mohammad Hamadei. In 1985, Hamadei highjacked TWA Flight 847, killing a United States Navy diver in the process. Hamadei was apprehended in Germany, and the United States requested that he be extradited to America. ${ }^{193}$ In an attempt to prevent Hamadei's extradition to the United States and obtain his release, terrorists kidnapped two German businessmen in January $1987 .{ }^{194}$

The terrorists succeeded in blocking Hamadei's extradition to the United States; however, he was tried in Germany where he was convicted and sentenced to life imprisonment. ${ }^{195}$ Following Hamadei's conviction,

186. Id.

187. Santosus, supra note 4 , at 28.

188. MACPHERSON, supra note 16, at 16.

189. Howard S. Levie, Evaluating Present Options For an International Criminal Court, 149 MIL. L. REV. 129, 130 (1995).

190. SENATE REPORT, supra note 32, at 25.

191. Marquardt, supra note 108 , at 140-41.

192. Id.

193. MACPHERSON, supra note 16 , at 18 .

194. Id.

195. Id. 
United States Senator Arlen Specter commended Germany for convicting him but expressed regret that the terrorists had coerced that country into prosecuting Hamadei in lieu of extraditing him to the United States. ${ }^{196}$ Specter concluded that the presence of a permanent international criminal court would have prevented the entire situation, including the abduction of two innocent civilians. ${ }^{197}$

The situations involving both Hamadei and the Libyan terrorists demonstrate that the United States would benefit from the creation of an international criminal court with supplemental jurisdiction over international terrorism. This proposition is also demonstrated by situations where the American government has been successful in prosecuting terrorists only by forcibly abducting the suspect. Situations where the United States must resort to self-help should be avoided because they endanger lives and create international tension. ${ }^{198}$

Perhaps the most notorious example of the American use of forcible abductions is illustrated in United States v. Alvarez-Machain. ${ }^{199}$ Humberto Alvarez-Machain, a Mexican national, was indicted for participating in the kidnapping and eventual murder of a United States Drug Enforcement Agent. ${ }^{200}$ Despite an extradition treaty between Mexico and the United States, the suspect was kidnapped from his office in Mexico by American agents, flown to Texas, and arrested. ${ }^{201}$ Following the defendant's apprehension, the Mexican government repeatedly protested the abduction, stating that it violated the extradition treaty. ${ }^{202}$

The United States Supreme Court ruled that the general rules of international law provided no basis for interpreting an extradition treaty as prohibiting international abduction even when the home state of the kidnapped defendant protests the abduction. ${ }^{203}$ Justices Stevens, Blackmun, and $O^{\prime}$ Connor dissented, worrying that the majority's decision could have adverse effects on the American citizenry. The dissenting Justices summarized their concerns by quoting Thomas Paine, who once stated: "[h]e that would make his own liberty secure must guard even his enemy from oppression; for if he violates this duty he establishes a precedent that will reach himself." 204

196. See generally 135 CONG. REC. S54, 63-64 (1989).

197. Id. at 64.

198. MACPHERSON, supra note 16 , at 16-17.

199. 504 U.S. 655 (1992).

200. The United States specifically alleged that the defendant, a medical doctor, kept the agent alive and conscious during prolonged periods of torture. Id. at 657.

201. Id.

202. Id. at 659 .

203. Id. at 669.

204. Id. at 688 (Stevens, J., Blackmun, J., and O'Connor, J., dissenting) (quoting 2 THE COMPlete WritingS of Thomas Paine 588 (P. Foner, ed., 1945)). 
The possibility that the United States has set a precedent that will reach its own citizens is all the more disturbing because America and many other countries have expanded their jurisdiction to foreign nationals who commit offenses that merely injure their citizens. ${ }^{205}$ This expansion of jurisdiction effectively means that an American citizen could be abducted by a foreign government-possibly one hostile to the United States-for committing offenses in the United States that allegedly violate the other country's law. However, even if the United States never has the precedent of AlvarezMachain used against its own citizenry, the decision still may have harmed the standing of the United States in the world community. Conrad K. Harper, a former legal adviser to the U.S. Department of State, commented that "[o]nly as a respecter of [the] law among its international neighbors can the United States maintain its rightful authority as a leader among nations. "206 Forcible abductions certainly do not respect the law of America's neighbors.

Because an international criminal court would provide an impartial means ${ }^{207}$ of investigating an alleged offense through its Prosecution and Presidency, it would provide a third party to which nations could turn for a determination as to whether a prima facie case rightly exists against a suspect. Thus, the establishment of an international criminal court would be an important step in reducing the number of situations necessitating the resort to extraterritorial abductions. ${ }^{208}$

The United States' claim that it can effectively deal with terrorism is based partly on its ability to impose economic sanctions on countries harboring terrorists. By prosecuting terrorists whose home states would not otherwise extradite them to the victimized nation, the establishment of the proposed international criminal court would reduce the use of economic sanctions. George Lamptey, the United Nations ambassador from Ghana, has commented that if an international tribunal existed, "Libya would not be suffering today because it refused to send its citizens for trial in a court in whose jurisdiction it lacked confidence. ${ }^{209}$ All nations, including the United

205. See generally Anderson, supra note 163, at 439-40.

206. SENATE REPORT, supra note 32, at 15.

207. See supra text accompanying notes $39-43$. See also Bhattacharyya, supra note 25 , at 76-78. The author notes that the draft statute proposing the creation of the International Criminal Court "strives to eliminate improper influences, bias and prejudice on two levels: (1) structurally, through provisions intended to ensure the independence and impartiality of the members of the Court, and (2) procedurally, through provisions intended to ensure that the process of adjudication is insulated from improper influences." Id. at 76. Cf. Marquardt, supra note 108, at 146 . The author notes that, under the current draft, the Presidency could use its influence to press a prosecution and appoint judges to try the case. The author concludes that these functions should be further separated to limit the ability of this small group to have so much influence over the prosecution. Id.

208. Bhattacharyya, supra note 25 , at 72 .

209. Deen, supra note 6. 
States, should attempt to reduce the use of economic sanctions for two reasons. First, the effectiveness of these sanctions in accomplishing their intended objective has always been debatable. Second, the imposition of sanctions often causes uninvolved countries to resent the sanctioning nation.

Currently, the United States and its allies are imposing economic sanctions against seven countries for supporting, tolerating, and engaging in international terrorism. The sanctioned countries are Cuba, Iran, Iraq, Libya, North Korea, Sudan, and Syria. ${ }^{210}$ Many scholars contend that sanctions such as these are never effective. At the very least, most commentators seem to agree that such sanctions are less effective in some situations than in others. ${ }^{211}$ For instance, the sanctions imposed on Cuba have been called a failure. ${ }^{212}$ This contention is supported by noting Cuba's continuing role as a safehaven for terrorists. ${ }^{213}$ For example, a number of Basque Fatherland and Liberty (E.T.A.) terrorists and fugitives from the United States who sought sanctuary in Cuba several years ago continued to live on the island in 1995. ${ }^{214}$

The most notable example of a nation under sanctions for harboring terrorists is Libya. Libya is being sanctioned for failing to extradite the two suspects accused of bombing Pan Am Flight 103, to pay compensation to the victims, and to cooperate with international authorities in the investigation. ${ }^{215}$ The sanctions against Libya have been only marginally successful because the extent of U.S. trading with Libya was already minimal before the imposition of trade prohibitions. ${ }^{216}$ Because the sanctions have not damaged the Libyan economy, Libya still has only agreed to yield the suspects over to an international forum. However, since no such court exists, the only recourse available to the United States is to increase the sanctions-which they intend to do-in hopes that they will one day succeed. ${ }^{217}$

210. Jerry Stilkind, State Department Releases Report on International Terrorism, USIA ELECTRONIC JOURNALS, Apr. 30, 1996 (visited Oct. 12, 1996) < http://www.usia.gov/topics/ terror/stlkart.html >.

211. See generally Marynell DeVaughn, Effects and Effectiveness of Economic Sanctions, 84 AM. SoC'Y INT'L L. PROC. 203, 206 (1990) (statement of Barry E. Carter, Professor of Law, Georgetown University Law Center).

212. Id. at 211 (statement of Covey T. Oliver, Professor Emeritus of International Law, University of Pennsylvania Law School).

213. U.S. DEPARTMENT OF STATE, supra note 2, at 27.

214. $I d$.

215. Id. at 29.

216. DeVaughn, supra note 211, at 207 (statement of Barry E. Carter, Professor of Law, Georgetown University Law Center).

217. Albright, supra note 171, at 1601-1602.

Libya has proposed a variety of schemes for trial, all of which have in common their lack of compliance with the resolutions of the Security Council that require a trial either in the United Kingdom or the United States. The United States has pushed hard to maintain sanctions to keep the pressure on [the] Qaddaffi 
The United States government has recognized that the existence of a permanent international criminal court could aid in reducing the need to resort to economic sanctions. ${ }^{218}$ The tribunal would provide a forum where nations could confidently send suspects, whom they are knowingly harboring, to receive an impartial trial. The American government also recognizes that, in reality, nations will remain unwilling to turn over their own nationals to an international tribunal when it is not in the nation's best interest to do so. ${ }^{219}$ However, no nation enjoys being permanently labeled as an international criminal. If the court could develop a reputation for fairminded adjudications, nations would feel a greater pressure to subscribe to and abide by its jurisdiction to avoid such a reputation. This would result in limiting the number of instances where sanctions become necessary. ${ }^{220}$

By providing an alternative to sanctions, the proposed international criminal court will benefit the United States and the world not only because sanctions are often ineffective, but also because they create global tension. For instance, the sanctions that have been imposed on Libya have carried negative repercussions for United States in their relations with other Islamic states. ${ }^{221}$

\section{CONCLUSION}

The problems accompanying the use of sanctions is only one reason that the United States should support the creation of an international criminal court with jurisdiction over terrorism. Other methods employed by the American government to bring terrorists to justice, such as extraterritorial abductions, also often inspire animosity towards the United States. In addition, the United States should respect the needs of less powerful countries whose only means to try terrorists may be an international criminal court.

Many of the concerns expressed by the United States surrounding granting the proposed court jurisdiction over terrorism have been alleviated by the recent draft statute that would establish the tribunal. For instance, restrictions on the election process ensure that those who would judge the accused will not be biased persons who hail from enemy nations. The draft statute also provides extensive due process protections that go beyond those

regime, and we would prefer stronger ones, including an arms embargo, if the Id.

Libyan leadership remains intransigent.

218. See generally SENATE REPORT, supra note 32, at 12-13.

219. Id. at 13.

220. Id.

221. DeVaughn, supra note 211, at 207 (statement of Barry E. Carter, Professor of Law, Georgetown University Law Center). 
of which defendants are currently assured under the current extradition process. The statute also protects the sovereignty of the United States and all nations involved by allowing victimized nations to choose which particular offenses the court may try.

In addition, the court would have more than adequate resources for trying cases of terrorism and could bring each case to a definite conclusion. The proposed court also would have a concrete body of law under which to prosecute terrorists: the existing international conventions proscribing terroristic conduct. Thus, granting the proposed court jurisdiction over terrorism would benefit not only the United States and the world, but also the tribunal itself by giving it the opportunity to build a positive reputation in the international community.

Steven W. Krohne*

* J.D. Candidate 1998, Indiana University School of Law-Indianapolis; B.S., 1993, Indiana University-Bloomington. 
